\title{
An Analysis of State Aid From Europe to New Zealand
}

\author{
Annemieke Karel ${ }^{*}$
}

\begin{abstract}
Where state aid is distorting competition and creating inefficiencies it should and can be (self-)regulated. The European system of external monitoring and disciplines that the countries within the European Union are agreeing to have imposed on themselves has proven to reduce state aid levels and thereby increase overall welfare. Other than those that stem from its WTO commitments, New Zealand has no such monitoring mechanisms or disciplines, yet does, as do many other countries, provide state aid in various forms across different sectors of the economy, including public services. It is therefore important to understand the rationales behind the provision of different types of state aid, as well as its potentially negative effects on welfare. The European experience can then function as a benchmark for New Zealand and other countries in the Asia-Pacific region when considering the design of state aid rules in the future.
\end{abstract}

JEL classification: F13, I18, I28, K21, K33.

Keywords: State Aid, Trade, Services, Antitrust

\footnotetext{
* The author acknowledges useful comments from Prof. Lewis Evans, New Zealand Institute for the Study of Competition and Regulation. Corresponding author: ISCR, PO Box 600, Wellington, New Zealand. The author currently works for the Netherlands Competition Authority. Email: A.A.M.Karel@nmanet.nl All views expressed in this article are those of the author and do not necessarily represent the views of, and should not be attributed to, the Netherlands Competition Authority.
} 


\section{Table of Contents}

$\begin{array}{lll}\text { 1. Introduction } & \text { p. } 3\end{array}$

2. Rationales for State Aid p. 4

2.1 Market Failure Rationale p. 5

2.1.1 Different types of market failure p. 5

2.1.2 Policy failure p. 6

2.1.3 Public / private competition p. 8

2.2 Intergovernmental Competition Rationale p. 9

2.2.1 The rationale p. 9

2.2.2 The critique p.10

2.3 Political Economy Rationale p.12

2.3.1 Leading theoretical approaches p.12

2.3.2 A two-way analysis of state aid p.14

$\begin{array}{lll}\text { 3. } & \text { State Aid Control } & \text { p.17 }\end{array}$

3.1 State Aid Control in the European Union p.17

3.1.1 The legal framework p.17

3.1.2 Supranational authorities p.19

3.2 Other Trade \& Aid rules p.20

$\begin{array}{lll}\text { 3.2.1 WTO Agreements } & \text { p.20 }\end{array}$

3.2.2 OECD “Gentlemen’s Agreement” p.21

3.2.3 Export credit control in the European Union p.23

4. Trade and Aid in Services $\quad$ p.24

4.1 Trade Policies in Services p.25

4.1.1 WTO / GATS p.25

4.1.2 European trade policy in services p.26

4.1.3 New Zealand trade policy in services p.27

4.2 Aid in Services $\quad$ p.28

4.2.1 Services aid in the European Union p.28

4.2.2 Services aid in New Zealand p.29

4.3 Public Services p.33

4.3.1 Services of general interest p.33

4.3.2 Public service compensation in the European Union p.34

4.3.3 Implications for public service compensation in

New Zealand $\quad$ p.36

$\begin{array}{lll}\text { 5. Conclusion } & \text { p.38 }\end{array}$

$\begin{array}{ll}\text { References } & \mathbf{p . 4 0}\end{array}$ 


\section{An Analysis of State Aid From Europe to New Zealand}

\section{Introduction}

State aid includes a wide variety of ways in which states, or governments, provide assistance to the economy. This assistance may have several objectives, ranging from largely social objectives, like supporting victims of a flood or earthquake, to largely economic ones, such as providing remedy for an economic disturbance such as high inflation or unemployment. The aid in question can take a variety of forms, such as state grants, interest relief, tax relief, state guarantee or holding, and/or provision by the state of goods and services on preferential terms. ${ }^{1}$

The two main rationales cited for the provision of state aid are (1) reducing or eliminating market failure of some form, often asymmetric information, and (2) strengthening performance of the economy. For instance, state aid may reduce the inefficiencies associated with externalities. Think of labour market imperfections that may be reduced as state aid contributes to easing labour market transitions, facilitating restructuring, sharing adjustment costs or perhaps promoting job creation. Other examples are the provision of state aid to increase environmental quality or promote innovation. State aid may also ameliorate financial and other market failures that differently affect small and medium sized firms, or promote the development of peripheral regions and facilitate the survival of fundamentally sound firms.

To the extent that state aid has beneficial effects that outweigh the deadweight welfare loss associated with the taxation that is required to finance it, it is socially desirable. ${ }^{2}$ However, it is not clear in many circumstances that state aid will, in fact, "solve" externality problems where these are intrinsic to economic activities. Where state aid gives certain firms or products favoured treatment to the detriment of other firms or products, it has the potential of seriously disrupting normal competitive forces. State aid initially aimed at "facilitating the survival of fundamentally sound firms" or "supporting small and medium sized firms" may, for example, turn into supporting inefficient firms as these firms become dependent on the financial

\footnotetext{
${ }^{1}$ European Union (2005a).

${ }^{2}$ The public finance literature elaborates on the deadweight welfare loss associated with taxation. See, for example, Stiglitz (2000).
} 
assistance they receive. Perhaps more reason for concern, however, are the competition and efficiency (including investment) distortions that may result from state aid where it is part of countries' strategic trade policies. These effects are even more concerning if the policies that create them are the result of political pressure by special interest groups, which is likely to be a third explanation for the provision of state aid.

To deal with cases of state aid that distort competition between Member States, the European Union has developed a state aid control mechanism reflected in Articles 87 and 88 of the European Treaty. ${ }^{3}$ Thus far, state aid control does not exist in other regions in the world. However, in addition to greater insight in the effects on public/private competition within countries, a better understanding of the interface between state aid and strategic trade policy is of considerable importance in this age of increasing globalisation and international trade flows. Trade in services appear to be particularly supported by state aid, which makes a closer look at services trade and aid all the more important as service sectors are expanding in most countries. In order to evaluate state aid, we need to look at the different rationales for the provision of aid and evaluate on a case-by-case basis whether these are indeed welfare enhancing justifications. To the extent that they are not, governments may need to be subject to stricter regulation than the commitments made in World Trade Organisation (WTO) Agreements.

This paper is organised as follows. Section 2 analyses the three rationales for the provision of state aid - market failure, intergovernmental competition, and political economy motives. Section 3 builds on this by examining the scope for state aid control and reviewing existing international rules and regulation. Section 4 pays special attention to trade and aid in services in Europe and New Zealand. Finally, Section 5 sums up the main findings and concludes on the rationales for state aid and the implications for international competition policy.

\section{Rationales for State Aid}

As indicated in the Introduction, there are three basic rationales for the provision of state aid. Two of them are often used by governments defending their provision of

\footnotetext{
${ }^{3}$ Throughout the remainder of this paper, the new numbering of the articles (as amended by the Treaty of Amsterdam (1999) will be used. Articles 87 and 88 were formerly articles 92 and 93 respectively.
} 
state aid: the market failure rationale and the intergovernmental competition rationale. These are justified either to correct for market failure, mainly due to asymmetric information resulting in undersupply of certain goods or services, or to strengthen the economy in order to improve the country's competitive position in the international arena. A third rationale, state aid as the outcome of the political economy game, is less frequently argued, but lobbying efforts may well be as determining of provision of state aid as are market failure and intergovernmental competition. However, for each of these rationales, counter-arguments and critiques can be formulated that identify the potential risks and/or inefficiencies that can result from state aid even if its provision can be justified by one of the above reasons.

\subsection{Market Failure Rationale}

\subsubsection{Different types of market failure}

In most market economies, the generic economic justification for the granting of state aid is the existence of market failure. Economic theory tells us there are different types of market failure that require different types of corrective measures. The provision of state aid is typically found in markets characterised by externalities, asymmetric information, and/or public good features.

Economic theory defines externalities as the effects of the activity of one entity on the welfare of another in a way that is not transmitted by market prices. ${ }^{4}$ The classic example is the effect of pollution by a large factory on the surrounding environment and its inhabitants. The presence of externalities has traditionally been one of the main arguments for the provision of public subsidies and other forms of state aid. In the case of pollution, for example, the objective of subsidies is to give the business sector financial incentives to cooperate in improving environmental quality. Another example of an externality that is used to justify state aid is the existence of imperfections in the labour or financial markets resulting from asymmetric information. Because the private cost of labour or financial market adjustments (or the cost of creating environmentally-friendly production techniques) exceed the social cost, it is argued, these socially-desired adjustments are undersupplied. A similar reasoning is often applied to investments in $R \& D$ and innovation - because the private

\footnotetext{
${ }^{4}$ Rosen (1995).
} 
benefits from $R \& D$ and innovation are smaller than the social benefits, most market systems are likely to lead to underinvestment in $\mathrm{R} \& \mathrm{D}$, thereby justifying public support for innovation.

The above examples may all supply the justification of the granting of horizontal aid, that is state aid crossing sectoral and geographical boundaries. However, market failure may also arise in certain industries, or in certain geographical areas only, in which case we speak of sectoral aid or regional aid respectively. Sectoral aid is mainly targeted to declining industries and firms in sectors that are newly exposed to market competition. The rationale for the first category is to spread the social costs of adjustment and enable reorganised firms to continue operations. Such aid, which may help to retrain workers that have been made redundant, facilitate restructuring, or preserve the sector entirely, is often justified on social or historical grounds, rather than arguments of economic efficiency, although these too have a role. Similarly, for sectoral aid to newly privatised firms, the aim can be to facilitate adjustment to a shift in market circumstances. Such aid can take various forms, including limiting competition. It is provided for various purposes that include shoring up the value of a state asset and meeting adjustment costs such as those associated with lay-offs.

Rationales for regional aid can be drawn from the new geographical economics literature. The main argument is that in the presence of congestion externalities and increasing returns to scale, the location decisions of private firms may be suboptimal from a social point of view; and that the state has sufficient knowledge and implementation skill to anticipate and correct this deficiency. ${ }^{5}$ In other words, economic activity may be relatively concentrated in some areas and almost non-existent in others. Regional aid may be aimed at correcting such socially suboptimal outcomes.

\subsubsection{Policy failure}

Martin and Valbonesi (1999) recognise that aid measures aimed at different types of market failure not only promise different benefits (which may justify exemption under Article 87(3)), but also carry the threat of different types of policy failure (which may render the net effect of the policy measure negative as far as overall welfare is

\footnotetext{
${ }^{5}$ See, for example, Krugman (1991).
} 
concerned). They outline the three categories of state aid measures, as well as their potential benefits and distortions, summarised in Table 1.

Table I: A Taxonomy of State aid

\begin{tabular}{|c|c|c|}
\hline Aid Type & Potential Benefit & Potential Distortion \\
\hline \multicolumn{3}{|l|}{ Horizontal } \\
\hline Employment & $\begin{array}{l}\text { Reduce labour market } \\
\text { imperfections }\end{array}$ & $\begin{array}{l}\text { Camouflaging operating } \\
\text { aid }\end{array}$ \\
\hline Environment & $\begin{array}{l}\text { Increase environmental } \\
\text { quality }\end{array}$ & $\begin{array}{l}\text { Camouflaging operating } \\
\text { aid }\end{array}$ \\
\hline $\mathrm{R} \& \mathrm{D}$ & Promote innovation & $\begin{array}{l}\text { Camouflaging operating } \\
\text { aid }\end{array}$ \\
\hline Rescue and restructuring & $\begin{array}{l}\text { Facilitate survival of } \\
\text { fundamentally sound firms }\end{array}$ & $\begin{array}{l}\text { Preserve fundamentally } \\
\text { unsound firms }\end{array}$ \\
\hline $\begin{array}{l}\text { Small and medium-sized } \\
\text { enterprises }\end{array}$ & $\begin{array}{l}\text { Ameliorate financial and } \\
\text { other market failures that } \\
\text { differentially affect small } \\
\text { firms; promote job } \\
\text { creation }\end{array}$ & $\begin{array}{l}\text { Create or preserve } \\
\text { fundamentally unsound } \\
\text { firms }\end{array}$ \\
\hline \multicolumn{3}{|l|}{ Regional } \\
\hline Regional & $\begin{array}{l}\text { Promote development of } \\
\text { peripheral regions }\end{array}$ & $\begin{array}{l}\text { Aid wars; channel more } \\
\text { aid to least developed } \\
\text { regions of wealthiest states } \\
\text { than to least developed } \\
\text { regions of less wealthy } \\
\text { states }\end{array}$ \\
\hline \multicolumn{3}{|l|}{ Sectoral } \\
\hline $\begin{array}{l}\text { Declining of } \\
\text { consolidating industries }\end{array}$ & $\begin{array}{l}\text { Ease labour market } \\
\text { transitions; facilitate } \\
\text { restructuring; share } \\
\text { adjustment costs }\end{array}$ & $\begin{array}{l}\text { Delay inevitable } \\
\text { reorganisation; favour } \\
\text { firms from richer } \\
\text { countries; less efficient } \\
\text { firms survive, more } \\
\text { efficient firms exit } \\
\end{array}$ \\
\hline Privatising industries & $\begin{array}{l}\text { Increases share of } \\
\text { economy guided by market } \\
\text { forces }\end{array}$ & $\begin{array}{l}\text { Artificial advantage for } \\
\text { former public firms }\end{array}$ \\
\hline
\end{tabular}

Source: Adapted from Martin and Valbonesi (2000).

Most forms of horizontal aid carry the potential of camouflaging operating aid or preserving fundamentally unsound firms to the extent that governments have difficulties monitoring the actual use to which subsidies are put. ${ }^{6}$ This reasoning is based on the more general argument that government intervention, when subject to

\footnotetext{
${ }^{6}$ This discussion does not consider the political economy of aid; that may include the allocation of aid to sections of society based upon political considerations. See section 2.3 .
} 
asymmetric information, may in fact constitute a policy failure if the result of the intervention differs from the targeted outcome. For example, firms may use the aid they receive for other purposes without the government being able to monitor and correct this. A possible solution is suggested by Martin and Valbonesi (2000), who rightfully remark that although the objective of the aid is to compensate for external costs to firms, these costs are only external because they have traditionally been defined as such. Amending property rights in a way that would internalise the costs of the 'externality' would have the same result, without the potential distortion of ending up providing aid simply for firms to keep operating.

State aid may increase the profitability of the subsidised firm at the expense of its rivals and thus generate an artificial competitive advantage. If different governments provide state aid to firms in similar sectors, aiming to enhance their position vis-à-vis their foreign competitors, the result may be an aid war in which both governments continue to provide state aid as long as the other does so (see section 2.2.2).

Finally, when aid is given to declining sectors, it is basically preserving the operation of inefficient firms and delaying inevitable reorganisation. In the worst case, efficient firms may be forced to exit the market because inefficient firms (perhaps in other countries) enjoy an artificial competitive advantage. The same kind of advantage is enjoyed by previously public firms when they receive aid to adjust to changing market circumstances.

\subsubsection{Public / private competition}

A particular case of horizontal state aid camouflaging inefficient and competitiondistorting operating aid is when such aid (whether in the form of subsidies, credit provision or other forms of support) is used by firms performing a (semi-)public task to compete with private providers in the same or related markets, usually within a country. A recent example is the aid provided to social housing corporations in the Netherlands which is used by the corporations to compete with private housing agents on the market for housing for people with high(er) incomes. European Commissioner Kroes from the Competition Directorate General has addressed the issue and stated that the aid provided to social housing corporations should only be used to provide 
housing to people with low incomes. ${ }^{7}$ To use the competitive advantage gained from flexible credit conditions and tax reliefs to compete with private housing agents on the market for housing for people with high(er) incomes is a prime example of state aid according to Article 87 of the EC Treaty. Similar reasoning applies to the provision of other (semi-) public services, to the extent that (semi-)public providers compete with private providers using the advantage derived from state aid. Though the aid in question is intended to support activities that compensate for market failure, it may actually result in operating aid, giving the (semi-)public provider(s) an unfair competitive advantage. In the extreme case, private providers may be forced to leave the market as a consequence (see section 4.2.2).

\subsection{Intergovernmental Competition Rationale}

\subsubsection{The rationale}

At least as important as the market failure rationale is what we will call the "intergovernmental competition rationale", also called the "other governments do it" rationale. ${ }^{8}$ In this case, governments provide aid simply to compete with other governments that do the same. Countries whose firms have to compete with firms that enjoy an artificial advantage because they receive state aid are bound to lose. The prospect of a resulting decrease in growth and welfare causes many governments to provide state aid as long governments in competing countries do. One of the instruments of state aid most embedded in today's modern economies are the so-called Export Credit Agencies (ECAs). The activities of ECAs include giving insurance or guarantees for the repayment of a loan by a financial institution to a buyer in a third country (buyer credit), giving insurance or guarantees against non-repayment of a credit extended by an exporter to a buyer in a third country (supplier credit) and providing direct loans or credits to third country buyers. ${ }^{9}$ The United States ExportImport Bank's mission statement indicates the importance of the intergovernmental competition rationale:

"Ex-Im Bank enables U.S. companies - large and small - to turn export opportunities into real sales that help to maintain and create U.S. jobs and

\footnotetext{
${ }^{7}$ See Het Financieele Dagblad (2005).

${ }^{8}$ Niskanen (2001).

${ }^{9}$ European Union (2005b).
} 
contribute to a stronger national economy [...] We also help to level the playing field for U.S. exporters by matching the financing that other governments provide to their exporters."

Similarly, though less expressly, the United Kingdom's Export Credits Guarantee Department's (ECGD) main focus is "to help UK exporters of goods and services to win business and invest overseas" and the objective of New Zealand Trade and Enterprise is "to improve the international competitiveness and sustained profitability of New Zealand businesses”. 1011

In their paper on international competition in government export financing, Evans and Oye (2001) recognise the intergovernmental competition rationale. They argue that this rationale centres on offsetting perceived unfair promotional efforts of foreign official export credit and aid programmes and add that "governments have matched and overmatched the terms and conditions offered by foreign competitors to level the playing field for national exporters”. As long as other governments continue to provide aid in the form of export credits or otherwise, governments are unlikely to reduce their support as it would worsen the country's competitive position and, consequentially, reduce economic growth and welfare. International rules on export credit provision are discussed in section 3.2.

\subsubsection{The critique}

It is interesting to note that while individual governments continue to provide state aid in order to avoid decreasing economic growth and welfare, they are likely to be better off if they all reduced the amount of aid they provide. This is a classic example of the "prisoners' dilemma” drawn from game theory. The textbook example is the support Boeing and Airbus received for years from the American and European governments respectively, but essentially every form of state aid that is provided as part of intergovernmental competition fits this model to a greater or lesser extent.

The Boeing-Airbus analysis rests on the assumption that either firm alone could earn profits making 150-seat aircraft, but if both firms try to produce them, both will make losses (due to the inability to enjoy increasing returns to scale, sunk investment, etc.). Further assuming that Boeing is able to commit to producing the

\footnotetext{
${ }^{10}$ United Kingdom Export Credits Guarantee Department.

${ }^{11}$ New Zealand Trade and Enterprise (2004).
} 
aircraft before Airbus is, the pay-offs are as indicated in Figure $\mathrm{I}$ and in the equilibrium, Boeing will produce the aircraft.

Figure I Two-Firm Competition

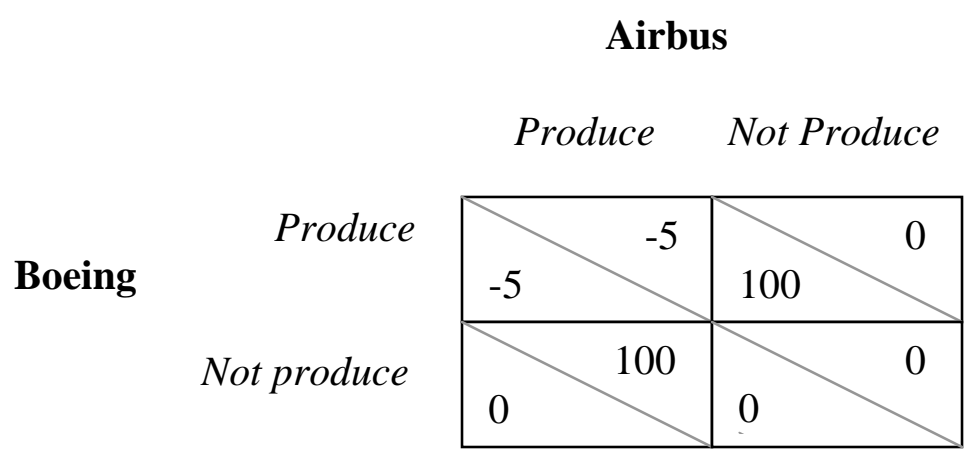

The classic Brander-Spencer (1985) argument says that in a situation of imperfect competition as depicted in this example, governments can influence the equilibrium outcome by subsidising domestic firms. For example, the European governments can reverse this outcome by subsidising Airbus and thereby changing the payoff matrix to that represented in Figure II. Airbus, now able to capture the market, ends up with profits of 125 instead of 0 , due to a subsidy of only 25.

Figure II The Effects of a Subsidy to Airbus

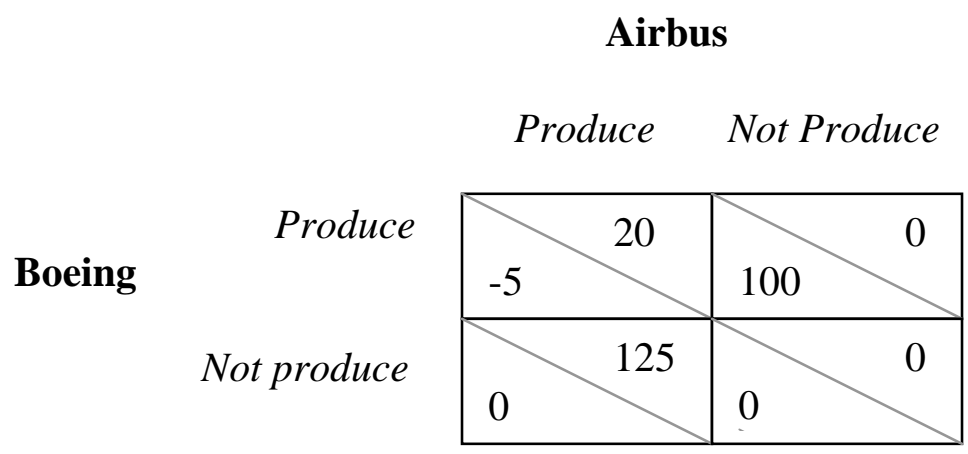

It is easy to see that subsidising is a dominant strategy for both governments, resulting in an equilibrium in which both firms receive subsidies that enable them to produce, ending up in a situation in which both firms actually produce. In terms of the BoeingAirbus example, both firms would have a payoff of 20. However, the respective 
governments provided subsidies of 25 each, implying the total change in welfare to each country is -5 ! The losers in this game are likely to be the consumers in both countries, as export subsidies and other forms of state aid are often financed with tax revenues.

The example illustrates the coordination problem of two countries in an industry that is relatively large. In such a circumstance the repeated plays of the competition game across time and products may assist in reaching a solution that is less punitive on the welfare of both countries: but the problem may also persist.

In some instances however, the fact that other countries are providing state aid is not a rationale for some other country to mimic that aid. Particularly, but not exclusively, where the latter country is small, by not engaging in me-too state aid it can enjoy the subsidised products of those countries that have instituted state aid. Small countries have no bargaining power with other, larger, countries and hence no game to play in negotiation about state aid in other countries: which is another reason for them to not mimic the state-aid activities of others. ${ }^{12}$

Aside from the above analysis, a discussion of intergovernmental competition requires a general equilibrium perspective. In addition to the industry-specific inefficiencies resulting from this prisoners' dilemma type of situation in intergovernmental competition, allocative inefficiencies may arise from drawing resources from other industries or from any legitimate state aid causes.

\subsection{Political Economy Rationale}

\subsubsection{Leading theoretical approaches}

In addition to market failure and intergovernmental competition motives, at least some proportion of state aid is likely to be motivated by political pressure from special interest groups. Though support for this is mainly found in empirical research in the international trade policy area, ${ }^{13}$ it should be noted that the results can also be applied to state aid as it bears many resemblances with, and can even be part of, strategic trade policy. According to some, "It is now commonplace to view trade

\footnotetext{
12 These and political economy issues for New Zealand's 1980s decisions on state aid are discussed in Evans and Richardson (2002).

${ }^{13}$ See, for example, Grossman and Helpman (1994), Baldwin (1985), and Tosini and Tower (1987).
} 
policy as an outgrowth of a political process that does not necessarily give rise to aggregate welfare maximization”. ${ }^{14}$

Within the political economy literature, there exist a few leading approaches to the formation of trade policies. One is the direct democracy approach, which was developed by Mayer (1984), who proposed to view trade policy as the outcome of majority voting over tariff levels. An alternative approach was proposed by Hillman (1982), building on the theory of economic regulation. Hillman presented the choice of a tariff rate (as a proxy for trade policy in general) as the solution to an optimising problem in which the government trades off political support from industry interests against the dissatisfaction of consumers (i.e., industry interests provide more support the higher the industry's profits, while the government gains more support from consumers the lower the consumer price. ${ }^{15}$ ). This approach is generally referred to as the political support approach. Findlay and Wellisz (1982), attempting to incorporate the effects of active lobbying for the protection of real incomes, proposed the use of so-called tariff-formation functions. These functions describe the level of protection afforded an industry as depending on the amount of resources devoted to lobbying by a group of supporters of protection on the one hand, and by the lobbying efforts of opposers of protection on the other. Finally, there are two approaches that focus on the role of contributions. Magee, Brock and Young (1989) emphasise the role of campaign contributions on electoral competition (i.e., campaign contributions can help a particular party getting (re-)elected), while others argue contributions are mainly driven by influence motives (see, for example, Grossman and Helpman (1994)).

Although the above approaches differ in focus, they all share a one-way perspective to the political influences on trade policy, i.e. they study the effects of trade policies pursued by a single country facing constant world prices. A more recent development in the political economy literature, following Putnam (1988), is the development of two-way models that incorporate the dynamics between domestic policies and international trade policies. As state aid is a domestic policy with the strong potential to influence terms of trade, this type of analysis appears most appropriate here. Particularly, Grossman and Helpman (1995) have extended the

\footnotetext{
${ }^{14}$ Grossman and Helpman (1995).

${ }^{15}$ The ability of the government to make this trade off is affected by industry interests being concentrated in number and resources that facilitate effective lobbying, whereas consumers are not concentrated (i.e. are diffuse) and so less effective in coordinating lobbying. See Helpman (1995).
} 
influence-driven contributions approach to a setting with two countries that set trade policies non-cooperatively.

\subsubsection{A Two-Way analysis of state aid}

Grossman and Helpman's (1995) two-way model is structured around a basic common agency problem, in which several principles try to induce a single agent to take a certain action. Here, the government acts as an agent for various special interest groups while being accountable for (potentially inefficient) implemented policies to the general electorate. This structure serves an appropriate political economy model to analyse the effects of state aid in a dynamic setting that captures both strategic interaction between interest groups and politicians in a domestic context and strategic interaction between governments in an international setting.

In the model of Grossman and Helpman (1995), the ad valorem trade taxes or subsidies drive a wedge between domestic and offshore prices. Though state aid is not only provided through fiscal measures, the effects on prices are comparable as it affects companies' cost and price structures in much the same way as do the trade policies in Grossman and Helpman (1995). The so-called "best response" trade (or aid) policies, incorporating the above price differences, maximise the joint welfare of each lobby and the government, when the contribution schedules of all other lobbies and the other country's trade policy are taken as given. The added value of the model is that the equilibrium policy outcomes are the sum of two components, indicated by Grossman and Helpman (1995) as the political support and terms-of-trade motives for trade intervention.

The political support component reflects a balancing of the deadweight loss associated with trade policies - that is borne by diffuse consumers - and the income gains that special interest groups can capture via such policies. This component can be illustrated as the simple case of an import tariff brought about by the lobbying of an organised import-competing industry in a small country facing fixed world prices (see Figure III). Due to the tariff, price rises from $P_{W}$, the world price, to $P_{W+T}$, the world price plus the import tariff. As a result, consumer surplus is reduced by area $a+b+c+d$. The income gain for the import-competing producers is area $a$. Area $c$ is the government's tariff revenue, and area $b+d$ is the deadweight loss that is created by the tariff. The political support component in the model of Grossman and Helpman 
(1995) basically reflects a balancing of areas $a$ and $b+d$, where differences in lobbying efforts lead to different policy outcomes. ${ }^{16}$

Figure III The effects of an import tariff as the result of lobbying in a small country

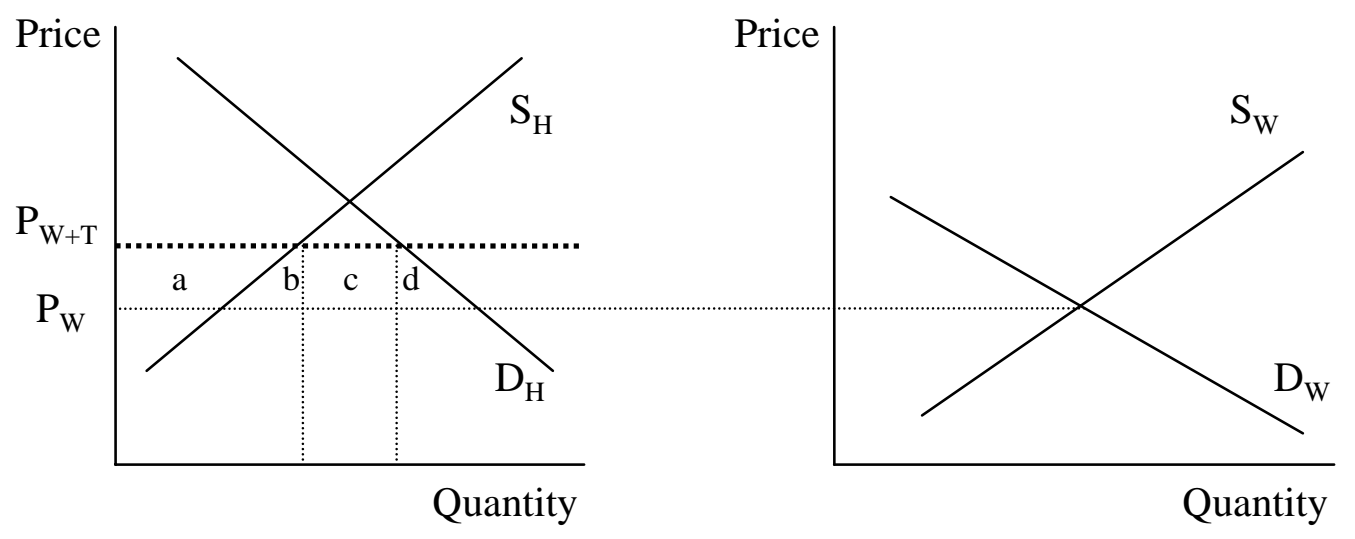

Home World

The second component reflects the fact that trade (or aid) policies can influence terms of trade and forms an additional reason for governments to tax international trade. Grossman and Helpman's (1995) terms-of-trade component can be illustrated as the case of an import tariff set by a large country. Figure IV shows the market for imports of a certain good or service, with the Home country's import demand given by the difference between domestic demand and supply $\left(D_{H}-S_{H}\right)$ and foreign supply indicated as $\mathrm{S}_{\mathrm{F}}$. The tariff drives a wedge between the domestic price of imports $\left(\mathrm{P}_{\mathrm{TH}}\right)$ and the price charged by foreign exporters $\left(\mathrm{P}_{\mathrm{TF}}\right)$. This results in a deadweight loss that comprises area $b+d$ (equivalent to areas $b$ and $d$ in Figure III) in the home country and area $f$ in the exporting country. The tariff-imposing country gains area $e$ by lowering the import price of the good or service in question at the expense of foreign suppliers and therefore improving its terms of trade. However, there is still a redistribution effect (consumer surplus is reduced by areas $c^{17}$ and $b+\underline{d}$ ) and a deadweight loss (hence inefficiency), and of course there is always the risk that

\footnotetext{
${ }^{16}$ For example, the model predicts that an organised import-competing industry emerges from a trade (aid) war with a protective tariff, whereas an unorganised export industry suffers an export tax.

${ }^{17}$ Though area $c$ is part of the tariff revenue for the government and may be returned to consumers by way of tax relief in other areas, for example.
} 
the exporting country will retaliate (in which case we could end up in a trade/aid war as described in section 2.2).

Figure IV The effects of an import tariff as the result of lobbying in a large country

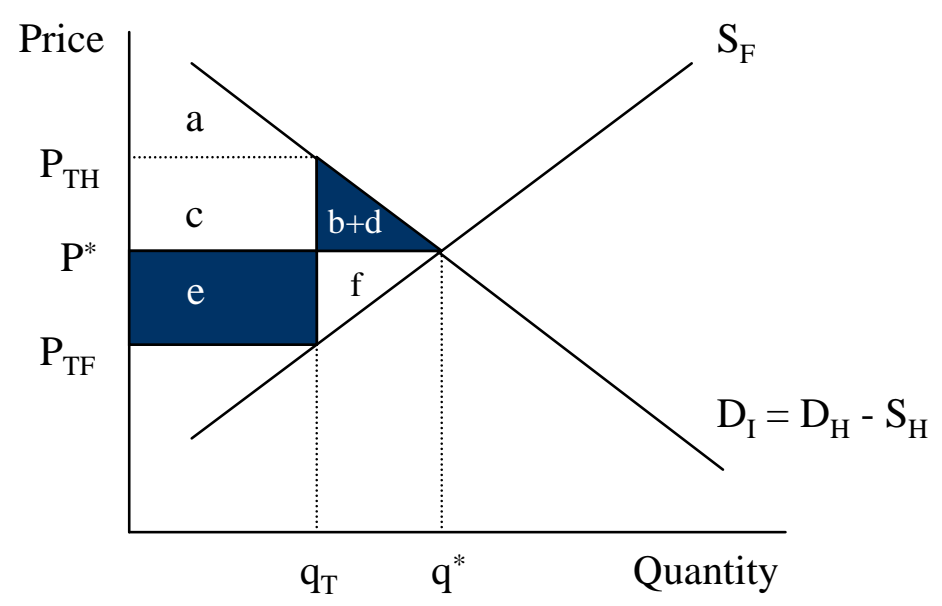

The effects of terms of trade on policy outcomes are reflected in a country's import demand or export supply elasticity, which is a function of that country's trade policy, the world price, and net imports. A country's market power in trade varies with the inverse of the foreign elasticity, i.e. the potential social gains from trade taxes (or other forms of state aid) become larger as foreign demand or supply becomes more inelastic (i.e. when $S_{F}$ in Figure IV becomes steeper, area $e$ becomes larger), which in turn may be a reason for industries to organise themselves or increase their lobbying efforts. In the case of constant elasticities, the model of Grossman and Helpman (1995) predicts that an increasing interest of the politicians in campaign or other contributions, relative to the general interest, will raise the profits of the organised factor owners in that country at the expense of their counterparts abroad, by inducing a change in the foreign country's policy that improves the home country's terms of trade.

By accounting for the effects of lobbying efforts and the terms-of-trade changes due to trade (or aid) policies, as well as the dynamics between them, the model of Grossman and Helpman (1995) provides us with greater insight into the possible effects of state aid motivated by political economy considerations. 


\section{State Aid Control}

The potential inefficiencies and competition-distorting effects that may result from state aid have been outlined in the previous section. In essence, these are the justifications for some form of state aid control as part of a region's or country's competition policy. So far, the only international political structure that enables the institution of and compliance with such a control policy framework is that of the European Union. However, international rules concerning a particular form of state aid, the provision of export credits, exist outside the EU as well (see section 3.2.2), possibly indicating the potential for (alternative) forms of state aid control in other areas of the world. Not only are the possible inefficiencies and competition-distorting effects from state aid compelling reasons for state aid control, but the EU experience has shown that state aid control is indeed effective. The latest update on the EU State Aid Scoreboard ${ }^{18}$ states that "From the relatively high levels of State aid in the early and mid-nineties, the overall volume of aid fell dramatically from €74 billion in 1996 to $€ 55$ billion in 1999. Between 1999 and 2001, total aid hovered around the $€ 55$ billion mark, rising to $€ 57$ billion in 2002 but then falling in 2003 by some $€ 4$ billion to $€ 53$ billion.”

\subsection{State Aid Control in the European Union}

\subsubsection{The legal framework}

The European Union (EU) is currently the only region in which state aid regulation exists. The EU has long recognised the potential of state aid to distort competition in the Common Market and as a consequence, it is prohibited by the EC Treaty. Article 87 of the EC Treaty (ex Article 92) states:

"Save as otherwise provided in this Treaty, any aid granted by a Member State or through State resources in any form whatsoever which distorts or threatens to distort competition by favouring certain undertakings or the production of certain goods shall, in so far as it affects trade between Member States, be incompatible with the common market.”

The European Court of Justice has consistently taken the view that "aid” means any advantage conferred on a firm by the public authorities, without payment, or against a

\footnotetext{
${ }^{18}$ European Union (2005).
} 
payment which corresponds only to a minimal extent to the figure at which the advantage can be valued. ${ }^{19}$ In addition, this aid needs to be state-financed and selective in character to constitute state aid for purposes of Article 87. For Article 87 to actually apply the state aid in question must also distort competition and affect trade between Member States.

The Treaty, however, does allow exceptions to the ban on state aid where the proposed aid schemes may have a beneficial impact in overall Union terms. Article 87 finds the following forms of aid shall be or may be considered to be compatible with the common market:

- aid having a social character, granted to individual consumers;

- aid to make good the damage caused by natural disasters or exceptional occurrences;

- aid to promote the economic development of areas where the standard of living is abnormally low or where there is serious underemployment;

- aid to promote the execution of an important project of common European interest or to remedy a serious disturbance in the economy of a Member State;

- aid to facilitate the development of certain economic activities or of certain economic areas, where such aid does not adversely affect trading conditions to an extent contrary to the common interest;

- aid to promote culture and heritage conservation where such aid does not affect trading conditions and competition in the Community to an extent that is contrary to the common interest;

- such other categories of aid as may be specified by a decision of the Council acting by a qualified majority on a proposal from the Commission

In addition, the European Commission has adopted a number of so-called "block exemption” regulations for state aid to small and medium-sized enterprises, aid for training, de minimis aid and aid for employment. ${ }^{20}$ This means that state aid falling

\footnotetext{
${ }^{19}$ European Commission (1997a).

${ }^{20}$ De minimis aid is aid granted by a Member State to an enterprise where the amount of aid involved is small. It is accordingly exempt from the competition rules. The total amount of de minimis aid may not exceed $€ 100,000$ over a three-year period.
} 
into these categories is automatically exempted from treatment under Article 87 and related state aid rules set out in the EC Treaty.

Other relevant, more sector-specific, provisions of the EC Treaty with respect to state aid are Article 36, which deals with the authorisation of state aid for the agricultural section only, Article 73, which states that aid shall be compatible with the Treaty if it meets the needs of coordination of transport or if it represents reimbursement for the discharge of certain obligations inherent in the concept of a public service, and Article 86, which regulates the treatment of public undertakings. In addition to Articles 88 and 89, that respectively deal with the role of the Commission and the Council with respect to state aid (see section 3.1.2), a number of procedural guidelines exist for notification, investigation and judgement of state aid cases.

There is an increasing awareness that actual or potential distortions of competition due to export-credit insurance may justify action by the Commission under the state aid rules. To this end, the Commission has published a Communication $^{21}$ and a later amendment to the Communication ${ }^{22}$ in the field of shortterm export credit insurance (see section 3.2.3).

The recent expansion of the European Union fosters new challenges in the area of state aid. ${ }^{23}$ To tackle these and existing challenges, the European Commission has recently adopted a State Aid Action Plan (2005) that outlines the guiding principles for a comprehensive reform of state aid rules and procedures over the next five years. $^{24}$

\subsubsection{Supranational authorities}

Whether or not aid granted by states is compatible with the relevant state aid legislation can only be determined by a supranational and independent authority. Within the European Union, the exclusive authority for scrutinising the state aid

\footnotetext{
${ }^{21}$ European Commission (1997b).

${ }^{22}$ European Commission (2001).

${ }^{23}$ During the period leading up to their accession on 1 May 2004, the new member states were obliged to notify the Commission of all aid measures still in force, and had to provide assessments from their respective competition authorities on these measures' compatibility with the existing EU laws. The notified and approved measures were to be included in an annex entitled 'existing aid' to the Accession Treaty. Following their accession, the EU's rules on state aid are enforced in the new member states by the Commission. See EurActiv (2005).

${ }^{24}$ European Commission (2005a).
} 
schemes of EU governments was conferred on the European Commission by Member States. The role of the Commission is laid down in Article 88 of the EC Treaty, which states that:

“The Commission shall, in cooperation with Member States, keep under constant review all systems of aid existing in those States. It shall propose to the latter any appropriate measures required by the progressive development or by the functioning of the common market.”

Member States need to inform the Commission of any plans to grant or alter aid, which will consequently be evaluated for authorisation by the Commission. If a Member State fails to comply with its obligation to notify and its obligation to await authorisation, the Commission may initiate proceedings either at its own initiative or for example in response to complaints from competitors. ${ }^{25}$ The Commission has the power to decide that state aid that is incompatible with the common market or that is misused shall be abolished or altered by the Member State concerned within a period of time to be determined by the Commission. In case of non-compliance with Commission injunctions or decisions by Member States, the Commission may refer the matter to the Court of Justice direct in accordance with Article 88(2) of the Treaty. ${ }^{26}$

The Court of Justice is the final arbiter on Community law. Its judges settle disputes over the interpretation and application of Community law. In this context, it means that Member States can appeal Commission decisions on state aid before the Court of Justice. The Court's judgements are binding on the Commission, on national governments, and on firms and individuals. Together with the legislation set out above, the case law of the Court of Justice provides for the legal framework for state aid cases in the European Union.

\subsection{Other Trade \& Aid Rules}

\subsubsection{WTO Agreements}

Being WTO members, the European Union's and New Zealand's trade support is subject to the WTO competition rules. Though state aid control as such does not yet exist within in a WTO framework, the General Agreement on Tariffs and Trade

\footnotetext{
${ }^{25}$ European Commission (1997a).

${ }^{26}$ European Union (1999).
} 
(GATT) and the General Agreement on Trade in Services (GATS) both recognize governments' rights to act against anti-competitive practices, and their rights to work together to limit these practices. The WTO's Working Group on the Interaction between Trade and Competition Policy emphasises the relevance of WTO principles to competition policy and the need for enhanced cooperation among Members in addressing trade impediments and anti-competitive practices.

The Agreement on Subsidies and Countervailing Measures introduces the concept of a 'specific subsidy': "for the most part, a subsidy available only to an enterprise or industry or group of enterprises or industries within the jurisdiction of the authority granting the subsidy." Only specific subsidies are subject to the disciplines set out in the Agreement. The Agreement deems the following subsidies to be prohibited: "those contingent, in law or in fact, whether solely or as one of several other conditions, upon export performance; and those contingent, whether solely or as one of several other conditions, upon the use of domestic over imported goods”. If it is found that the subsidy is indeed prohibited, it must be immediately withdrawn. If this is not done within the specified time period, the complaining member is authorised to take countermeasures. ${ }^{27}$

In addition, the WTO Agreement on Agriculture specifically discusses export competition and the reduction of export subsidies in the agricultural sector in Article 8 and 9. ${ }^{28}$ A WTO Secretariat Study in 2001 concluded that although world trade has been liberalized considerably as a result of the Uruguay Round, significant trade barriers remain, including in the agricultural sector. ${ }^{29}$ Further negotiations on export subsidies and competition between the WTO Members are currently taking place, shifting focus away from broader over-arching principles to details under specific headings. ${ }^{30}$

\subsubsection{OECD "Gentlemen's Agreement"}

Under the heading of another international organisation, the OECD, a number of countries have agreed to be an official participant in the Arrangement on Officially

\footnotetext{
${ }^{27}$ WTO Agreement on Subsidies and Countervailing Measures.

${ }^{28}$ WTO members were further required to reduce the value of mainly direct export subsidies to a level 36 per cent below the 1986-90 base period level over the initial six-year implementation period (19952001), and the quantity of subsidised exports by 21 per cent over the same period. Conditions for developing countries are less stringent. See the WTO Agreement on Agriculture.

${ }^{29}$ WTO (2001).

${ }^{30}$ WTO (2004a).
} 
Supported Export Credits. As is stated in its introduction, the main purpose of the Arrangement is to provide a framework for the orderly use of officially supported export credits. In practice, this means providing for a level playing field (whereby exporters compete on the basis of the price and quality of their products rather than the financial terms provided) and reducing subsidies and trade distortions related to officially supported export credits. ${ }^{31}$

The Arrangement first became effective in 1978, and has since incorporated a number of amendments that have been proposed over the years, most recently in July $2005^{32}$. Current participants are the EU, Australia, New Zealand, Canada, Japan, Korea, Norway, Switzerland and the United States. According to the OECD, "the role of the OECD in this area first and foremost involves the maintenance and development of disciplines (the Export Credit Arrangement) stipulating the most generous financial terms and conditions for officially supported export credits. The OECD also provides a forum for discussion and coordination of national export credit policies.”

It is important to note that although it is serviced by the OECD Secretariat, the Arrangement is not an OECD Rule. It is, rather, a “Gentleman's Agreement” between certain countries which are all Members of the OECD. In accordance, the participants do not form an official OECD body, though they meet under the auspices of the OECD and with support from the OECD Secretariat. The status of the Arrangement has been strikingly described as one of "useful ambiguity”. ${ }^{33}$

The Working Party on Export Credits and Credit Guarantees (Export Credit Group, ECG) is an official OECD body with a separate, albeit similar, membership. All OECD countries, with the exception of Iceland, are Members of the ECG. The European Commission participates fully in the ECG meetings, which are also attended by the International Union of Credit and Investment Insurers (the so-called Berne Union); the WTO is an Observer and other organisations, e.g. World Bank, IMF, UNEP, EBRD, are invited to meetings when issues of mutual interest are discussed. The ECG is made up of senior government officials responsible for the formulation of export credit policies, accompanied by senior officials of the export credit institutions. The general objectives of the ECG are to evaluate export credit

\footnotetext{
${ }^{31}$ OECD (2005).

${ }^{32}$ The latest amendment contains new provisions applicable to repayment profiles, to project financetype transactions and to projects in the renewable energy and water sectors.

${ }^{33}$ OECD (2005).
} 
policies, determine the problems which arise, and resolve or mitigate these problems by multilateral discussion. ${ }^{34}$

\subsubsection{Export credit control in the European Union}

Due to the existing trade provisions in the EC Treaty and the agreements in place within the OECD and WTO, the European Commission has not systematically intervened in the field of export credits. However, the 1997 Commission Communication regarding the application of Articles 87 and 88 to export credit insurance ${ }^{35}$ stated that work by the Council's Export Credits Group and cases before the Court of Justice had shown that "in the area of short-term export-credit insurance, the actual or potential distortions of competition in the Community may justify action by the Commission under the State aid rules without waiting for progress on other fronts.” The Report of the Council's Export Credits Group distinguishes 'public or publicly supported export-credit insurers' which include the official export-credit agencies as well as some privately owned and controlled export-credit insurers that are supported by their governments, and 'private export-credit insurers', which are mainly or exclusively engaged in the short term and which do not operate for the account or with the guarantee of the state for any of their business. Where these public or publicly supported export-credit insurers are in competition with any private insurers, they enjoy financial advantages which could distort competition against private insurers, in which case the public support would constitute state aid under Article 87.

The 1997 Communication defines 'marketable' risks as commercial risks on non-public debtors established in the European Union, Australia, Canada, Iceland, Japan, New Zealand, Norway, Switzerland, and the United States of America. The 2001 Amendment to that Communication amended the definition of marketable risk to include political risks arising within the same countries. The Communication clearly states that the exceptions provided for in Article 87 of the Treaty do not apply to aid for the insurance of marketable risks: "The distorting effects of such aid in the Community outweigh any possible national or Community interest in supporting exports.” It is added that this view has been confirmed by the Court of Justice. In Les

\footnotetext{
${ }^{34}$ Idem.

${ }^{35}$ European Commission (1997b).
} 
Assurances du Crédit SA and Compagnie Belge d'Assurance Crédit SA v Council of the European Communities and Commission of the European Communities (Case C63/89), the Court held that although the Directive on partial harmonisation of equalisation reserves for insurance companies, which exempted export-credit insurance operatings for the account of or guaranteed by the State, was not unlawful, the factors distorting competition between private and public or publicly supported export-credit insurers might justify recourse to legal action to penalize infringement of the provisions of Article $87 .^{36}$

The 1997 Communication specifically does not deal with the insurance of medium and long-term export-credit risks which are considered largely nonmarketable. In these areas, efforts to harmonize the terms of export-credit insurance, premiums and country-cover policy like the agreements made within the WTO and the OECD appear more appropriate.

\section{$4 \quad$ Trade and Aid in Services}

Services currently make up approximately $64 \%$ of world GDP, ${ }^{37}$ and trade in services is increasing. International trade rules and policies have been formulated in response in the form of the GATS. In Europe, state aid to service providers increased during the second half of the 1990s and only started to decline in response to stronger European pressure to decrease state aid levels in the beginning of 2000, while state aid to manufacturing has been decreasing since the early 1990s. As such pressure from surrounding countries or a supranational authority such as the European Commission does not exist in other regions (yet), the presence of state aid in services compensation is likely, particularly where those services are the subject of strategic trade policies. It should be noted that because of the nature of competition in services (focus on quality; non-price competition), state aid may come in many forms other than the obvious grants and subsidies. ${ }^{38}$

\footnotetext{
${ }^{36}$ Idem.

${ }^{37}$ CIA World Factbook (2005).

${ }^{38}$ For an extended analysis of the nature of services and the implications for competition policy, see Karel (2004).
} 


\subsection{Trade Policies in Services}

\subsubsection{WTO / GATS}

The increasing importance of services led to their inclusion in the Uruguay Round of trade negotiations. The central set of rules, the GATS, was to a great extent directly modelled on the General Agreement on Tariffs and Trade (GATT) and relies on many of the same principles. There are supplementary agreements - some in the form of annexes to the GATS, others embodied in Ministerial decisions - which deal with specific sectoral and other issues. In addition, each WTO member has a national schedule, which sets out commitments to not impose greater restrictions than are specified on the supply of services by other members.

Part I of the GATS (Article I) defines the scope and coverage of the GATS. The agreement applies to measures by WTO members which affect trade in services. ${ }^{39}$ Article I defines trade in services in terms of four different modes of supply: crossborder, consumption abroad, commercial presence in the consuming country, and presence of natural persons.

Part II sets out "general obligations and disciplines”. Unlike obligations under the GATT, the GATS obligations of each member depend significantly on what it has specifically undertaken, in its own schedule, to do. According to the WTO "The fact that the GATS rules are still necessarily untested, and that the services schedules are much more complex than those for goods, adds to the difficulty of assessing exactly what rights and obligations WTO members have assumed under the services package". ${ }^{40}$ The main general obligations for members under Part II are to "extend immediately and unconditionally to services or services suppliers of all other Members treatment no less favourable than that accorded to like services and services suppliers of any other country" 41 and to publish promptly 'all relevant measures of

\footnotetext{
${ }^{39}$ Article I(3) of the GATS excludes "services supplied in the exercise of governmental authority". These are services that are supplied neither on a commercial basis nor in competition with other suppliers.

${ }^{40}$ WTO (1999).

${ }^{41}$ According to the WTO, "a member is permitted to maintain a measure inconsistent with the general Most Favoured Nation (MFN) requirement if it has established an exception for this inconsistency. During the Uruguay Round, it became clear that unqualified liberalization in some service sectors could not be achieved, and that liberalization subject to some temporary MFN exceptions would be preferable to no liberalization at all. The result was that more than 70 WTO members made their scheduled services commitments subject to a further list of exemptions from Article II. [...] Apart from services specified in individual MFN exemption lists, the only permitted departure from mostfavoured-nation treatment under the GATS is among countries that are members of regional trading arrangements.”
} 
general application' (that is, measures other than those which involve only individual service suppliers) that affect operation of the agreement”.

In addition, there are a number of specific commitments, which are described in Part III. They involve the commitment to negotiate and provide market access, as well as giving national treatment, i.e. not discriminate between domestic and foreign service suppliers. These requirements apply only to scheduled sectors. Sectors that, according to the member governments, need special treatment are air transport, financial services, telecommunications and maritime transport services.

In Part IV, Article XIX provides that WTO members will continue to hold "successive rounds of negotiations with a view to achieving a progressively higher level of liberalization” of trade in services. Finally, Part V and VI contain institutional and final provisions including dispute settlement and definitions.

During the Uruguay Round of negotiations (1986-1994), participating countries made market-access commitments and exemptions on a number of services sectors at the same time. These commitments and exemptions are contained in their original services schedules. In addition to the services schedules, the WTO undertakes regular reviews of individual countries' trade policies to ensure transparency and stimulate adherence to the rules of the GATS. These Trade Policy Reviews review countries’ general trade policy framework, as well as sectoral policies.

\subsubsection{European trade policy in services}

According to the WTO’s latest European Communities Trade Policy Review ${ }^{42}$, services accounted for $71 \%$ of the EC-15's real GDP in 2002, though the size of the sector varied considerably across member States. ${ }^{43}$ The EC-15 is the world's leading services trader, accounting for $25 \%$ of exports and $23.8 \%$ of imports in 2001, excluding intra-EC trade. In the new member states, the C-10, services accounted for $65.2 \%$ of GDP in 2002 on average. ${ }^{44}$

\footnotetext{
${ }^{42}$ WTO (2004b).

${ }^{43}$ The share of services in total employment ranged from $56 \%$ in Portugal to $76 \%$ in the Netherlands; in terms of value added, services represent between 60\% (Ireland) and 80\% (Luxembourg) of the total. See European Commission (2002).

${ }^{44}$ Some of the acceding countries (e.g. Hungary, Estonia, the Czech Republic, and the Slovak Republic) have been adjusting their industrial structures and upgrading their exports product quality, but others (such as Latvia and Lithuania) are still more labour-intensive or natural-resource-intensive.
} 
European economic growth has generally slowed down since 2001 and this weak productivity growth has been particularly apparent in the service sector. ${ }^{45}$ In addition, the service sector has been lagging behind other sectors in creating a single market, which, according to the WTO Trade Policy Review, is largely because of differences in regulation across member states and "red tape". One of the most important mid- and long-term goals for reforms in the European Community is to create that single market for services by further improving free movement of services between countries and (further) liberalising specific service subsectors, in order to boost the overall competitiveness of the region's economy. In particular, action plans for reform have been drawn up for financial services, telecommunications, transport, and liberalisation of the energy sector continues.

Under the GATS, the EC scheduled commitments across virtually all major service categories, though maintains so-called MFN exemptions under Article II. In parallel to the WTO work, the EC is also pursuing trade facilitation in regional and bilateral initiatives. ${ }^{46}$ In the ongoing negotiations, the European Union does not seek to dismantle public services. No requests are being made on health services and only the United States has received a request limited to privately funded higher education. The European Union stresses that "GATS negotiations are about opening up service trade, not about deregulating services many of which are closely regulated for very good reasons”. ${ }^{47}$

\subsubsection{New Zealand trade policy in services}

The service sector is the largest sector in New Zealand, at around 68 percent of GDP in $2004{ }^{48}$ The main exports are education, professional services, travel, and transport. Currently, tourism and related services is one of the fastest growing service exports. ${ }^{49}$ State intervention appears to be minimal in most services. However, the Government owns three main electricity generators/retailers, and maintains significant state ownership in the transport sector. Sector-specific policies are in place in the telecommunications and electricity markets.

\footnotetext{
${ }^{45}$ According to the WTO Trade Policy Review, explanations can be found in the appreciation of the euro, the fear of terrorism that followed the 11 September 2001 attacks (deterring travel), as well as an insufficient use of information and communication technologies.

${ }^{46}$ European Union (2004a).

${ }^{47}$ European Union (2004b).

${ }^{48}$ CIA World Factbook (2005).

${ }^{49}$ WTO (2003).
} 
New Zealand's WTO services schedule shows very few limitations to the commitments of market access and national treatment. According to the WTO's latest New Zealand Trade Policy Review, New Zealand has generally "maintained an open and highly transparent trade and investment regime, based on regular and widespread public consultations”. In addition, it participates actively in the WTO, grants at least MFN treatment to all WTO members, and has submitted several proposals in the Doha Development Agenda negotiations. However, in recent years, it seems as if New Zealand has limited efforts to liberalise trade. In 2000, further unilateral tariff reductions were suspended until 2005, pending ongoing review. In 2001, the Export Credit Office was established to provide assistance for insurance or guarantees to small and medium-sized exporters. In addition, the WTO's Trade Policy Review mentions that "in contrast to the 1980s and 1990s, when there was a concerted policy to reduce state ownership, the policy since 1999 has been to halt further privatisations especially of assets considered to be strategic”. These measures seem to mark change that departs from what is implied by state aid principles and rules.

\subsection{Aid in Services}

\subsubsection{Services aid in the European Union}

The European Union is currently the only region in which individual states are encouraged to measure and report the state aid they grant. This incentive is strengthened by the monitoring and enforcing powers of the European Commission. State aid amounted to $0.99 \%$ of EU Gross Domestic Product (GDP) in 2001, compared to $1.16 \%$ in 1997 . On the observed reduction in state aid, former Competition Commissioner Mario Monti commented:

"The system of State aid control has imposed a very healthy discipline on the fifteen Member States, each of whom pledged at the Stockholm European Council to reduce the overall amount of aid granted by 2003 and redirect aid to horizontal objectives of common interest. Most are already on the right track with levels of aid falling steadily and aid being reoriented to objectives such as the environment and research and development. Nevertheless, the cumulative effect of some $€ 86$ billion of State aid in 2001 still has a considerable distortive effect on competition in the Internal Market."50

\footnotetext{
${ }^{50}$ European Commission (2003a).
} 
As indicated in Figure V, services, including tourism, financial, media and culture, received 6\% of total state aid in the European Union in 2003. By far, most state aid is granted to the agriculture and manufacturing sectors. Still, 6\% of roughly €86 billion amounts to more than $€ 5$ billion, which seems more than sufficient to suggest the potential of distortion in services competition.

Figure V Share of State Aid by Sector, 2003

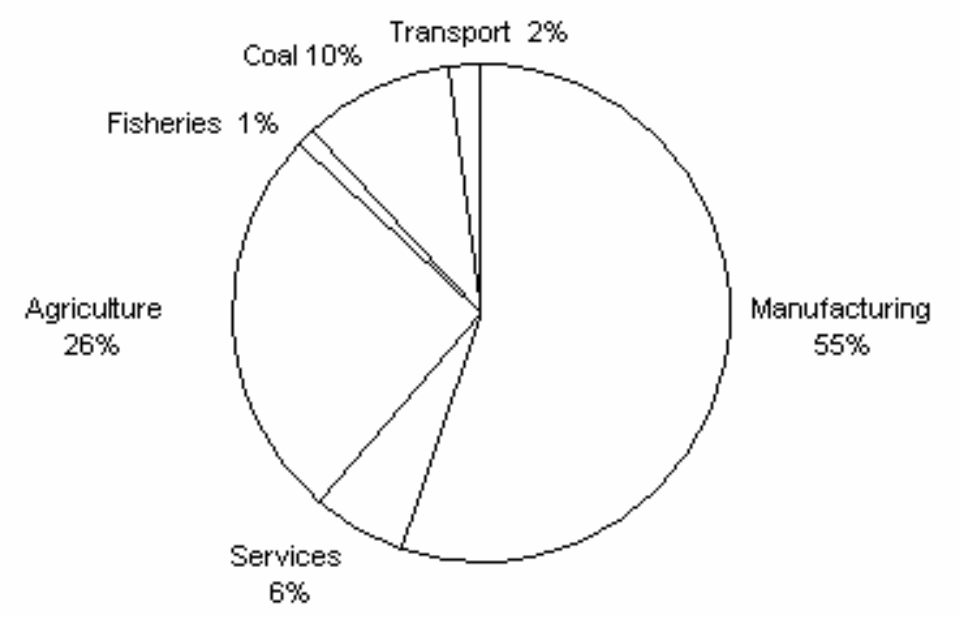

Source: Adapted from European Union, State Aid Scoreboard Key Indicators Spring 2005

Until further specification according to aid instrument is reported (as is done for manufacturing), we can only evaluate aggregate numbers. However, statistics for individual Member States reveal that Germany and France grant more aid to services than most other European countries, both in absolute and relative terms. In terms of percentage of GDP, Portugal spends relatively most on services. When the postexpansion data become available, we will be able to see to what extent the distribution of state aid has changed after the inclusion of the new member states.

\subsubsection{Services aid in New Zealand}

In New Zealand, subsidies are granted to both public and non-public services, such as health, education, business services, broadcasting, film production, land transport, and tourism services. Most aid is provided through the various Ministries, the New Zealand Export Credit Office, and New Zealand Trade and Enterprise, the New 
Zealand Government's trade and economic development agency. What follows is a short outline of the aid measures in various private and semi-public service markets. ${ }^{51}$ This list is not exhaustive and it should be noted, that the aid measures discussed below do not necessarily constitute state aid of the kind that would be deemed illegal under the European law (see also section 4.3). However, they do contribute to the overview of total aid provided in New Zealand service industries. Also, there are potential other aid mechanisms at work such as state ownership of Air New Zealand.

\section{Business services}

Most of the funding to business is provided by the New Zealand Trade and Enterprise (NZTE), which is “the New Zealand Government's agency charged with helping New Zealand businesses achieve success at home and in the global marketplace” that strives "to improve the capability and international competitiveness of New Zealand businesses". ${ }^{52}$ NZTE mainly offers market intelligence and market development services. The funding NZTE received from the New Zealand government for the year 2003/04 was $\$ 44.656$ million.

In addition, business is supported by the New Zealand Export Credit Office (ECO), which became operational on 1 July 2001. Its purpose is "to provide export credit guarantees to support the export activity of New Zealand firms and businesses". ${ }^{53}$ An export credit guarantee is a form of insurance that covers an exporter if the importer or his/her bank defaults on payment. The Government's maximum liability under the scheme is limited to $\$ 350$ million. It is not clear what proportion of export credit guarantees is provided for services export. However, compared to other Export Credit Agencies (ECAs), the New Zealand ECO offers only limited services. In terms of the Review of the New Zealand Export Credit Office (2002), the ECO is a 'guarantor only' ECA (as opposed to a 'financing also' ECA).

With respect to energy services (and industrial processes), the New Zealand government has been implementing Negotiated Greenhouse Gas Agreements (NGAs), which provide carbon tax reductions - in return for some management of greenhouse gas emissions, to "[...] firms or industries that, as a result of the carbon tax, face

\footnotetext{
${ }^{51}$ Public service compensation is discussed in section 4.3.3.

${ }^{52}$ New Zealand Trade and Enterprise (2004).

${ }^{53}$ New Zealand Export Credit Office.
} 
significant risk to their competitiveness relative to producers in countries with less stringent climate change policies”.

\section{Education}

Education in New Zealand is provided by public and, to a lesser extent, private providers. Annually, the New Zealand government appropriates approximately NZ\$8 billion for education purposes, including funding, benefits, research etc. through the Vote Education programme. ${ }^{54}$ It allocates NZ\$ 146 million annually to private training establishments (PTEs) for the provision of tertiary education. In addition, funding is allocated to post-compulsory education and training. ${ }^{55}$ Industry training is funded jointly by the government (approximately NZ\$ 98 million in 2004 ${ }^{56}$ ) and industry via non-Government Industry Training Organisations. Another large part of funding (approximately $\$ 97$ million in $2004^{57}$ ) goes to second chance education, in the form of the Training Opportunity Programme, which provides a tuition subsidy to educationally disadvantaged trainees, provided by private, charitable and state education providers.

\section{Broadcasting}

The New Zealand Broadcasting Commission, NZ On Air, a crown entity, funds programmes and broadcasts, not otherwise provided in a commercial market that reflect and develop New Zealand identity and culture. Funding used to come from the public broadcasting fee revenue collected by the Broadcasting Commission, but has been provided by the New Zealand government since the abolishment of the broadcasting fee in 2000. In the 2004/2005 financial year, total funding amounted to NZ\$ 96.5 million, roughly two-thirds of which was spent on television programming, and the rest allocated to public radio programming and non-programming statutory functions. ${ }^{58}$ As the nature of the service being supported means there is no fixed unit cost, the amount of funding to be provided is determined on a project-by-project basis.

\footnotetext{
${ }^{54}$ See Ministry of Education (2003/2004).

${ }^{55}$ Ministry of Education (2002).

${ }^{56}$ Tertiary Education Commission (2004).

${ }^{57}$ Idem.

${ }^{58}$ NZ On Air (2005).
} 


\section{Film Production}

The New Zealand Film Commission supports the production of film through investment, marketing, industry support and other activities, "to encourage creative and sustainable production of quality New Zealand feature films, to encourage the development of creative talent, and facilitate a dynamic film environment in New Zealand, and to stimulate local and international market intersession, and to attract investment to, New Zealand film”. The New Zealand Film Production Fund Trust (the Film Fund) was established in June 2000 following a NZ\$22 million contribution from the New Zealand Government. As with broadcasting services, there are not fixed unit costs and the amount of funding is determined on a project-to-project basis.

\section{Land Transport}

Support for public passenger transport services in the form of grants to Regional Councils is provided by the National Roads Account, coming from excise duty on petrol, road user charges and motor vehicle licensing fees. The argument for supporting public transport services is to stimulate public transport and thereby reduce the externalities associated with private transport (i.e. pollution, congestion, and safety costs), and to provide a social service to the transport disadvantaged. The annual amount of funding is estimated at $\$ 30$ million.

\section{Tourism}

Aid to tourism services is provided through the New Zealand Tourism Board (NZTB), known as Tourism New Zealand. The NZTB was established as a Crown Entity by the New Zealand Tourism Board Act 1991. It is the international marketing agency responsible for the promotion of New Zealand. The WTO's New Zealand Trade Policy Review (2003) reports that "the Government has also played a role in the promotion and leveraging of major events such as in yachting (the Louis Vuitton Challenger Series, the America's Cup series) and the release of the The Lord of the Rings films; it also has a role in managing some tourism-related properties”. In the year ended 30 June 2004, Tourism New Zealand and its subsidiaries received approximately $\$ 60$ million in government grants. ${ }^{59}$

\footnotetext{
${ }^{59}$ Tourism New Zealand (2005).
} 


\section{Conclusion}

The amounts of aid provided for the provision of the services outlined above seem to confirm the 2003 WTO’s Trade Policy Review’s observation that "state intervention in most services is minimal”. However, like services competition itself, many forms of state aid in service markets are relatively non-transparent, and their presence has the potentiality of increasing the amount aid provided. Examples are the potential artificial advantages created by (partial) state-ownership or control, as is the case for Air New Zealand and the so-called 'Kiwibank'. According to the New Zealand Trade Policy Review (2003) "the perception that Kiwibank deposits might benefit from an implicit government guarantee could confer it with an advantage over private banks, which do not enjoy such a guarantee”. Similarly, state involvement in transport services remains high, even after systematic deregulation since the late 1970s.

As long as there is no requirement for governments to report the aid they grant, in whatever form, evaluation of levels and trends in state aid will have to be based on individual projects and measures that are most visible. Services are plagued with difficulties of measurement, and the effects of much state aid are hard to quantify.

\subsection{Public Services}

\subsubsection{Services of General Interest}

The GATS does not cover those services "supplied in the exercise of governmental authority”, these being defined as services which are neither supplied on a commercial basis nor in competition with other service suppliers. ${ }^{60}$ Examples may include certain financial services, social security, health, and education. It is typically argued that market supply for these services is often insufficient or even non-existent due to the presence of market failure. Particularly, asymmetric information and public good characteristics (i.e. limited excludability and rivalness in consumption) where they arise may cause market supply to be below the social optimum, justifying some form of government intervention. So far, this line of reasoning is similar to the market failure rationale analysed in section 2.1.1. However, more than most other goods and

${ }^{60}$ GATS, Article 1.3(b) and 1.3(c). 
services, public services serve the general interest and any financial compensation or other aid that facilitates the provision of these services should be analysed with care.

In a recent Green Paper of the European Commission (2003b), the subject matter of public services, or "services of general interest” (SGIs), is acknowledged to be complex:

"The reality of services of general interest which include services of both general economic and non-economic interest, is complex and constantly evolving. It covers a broad range of different types of activities, from certain activities in the big network industries (energy, postal services, transport, and telecommunications) to health, education and social services, of different dimensions, from European or even global to purely local, and of different natures, market or non-market.”

Nevertheless, financing of public services may in some cases entail competitiondistorting state aid, which is why the European Union has published a framework paper on the matter and why other countries may want to consider similar rules.

\subsubsection{Public service compensation in the European Union}

The European Commission has recently published a Community framework paper for public service compensation. ${ }^{61}$ As is stated in the first paragraph of the framework paper: "It results from the case law of the Court of Justice that public service compensation does not constitute state aid within the meaning of Article 87(1) of the Treaty if it meets certain conditions" (italics added). The paragraph refers to the decision in Altmark Trans GmbH and Regierungspräsidium Magdeburg $v$ Naverkehrsgesellschaft Altmark $\mathrm{GmbH}$, in which the Court held that for a state measure to be classifiable as state aid within the meaning of the EC Treaty, it must be capable of being regarded as an 'advantage' conferred on the recipient undertaking which that undertaking would not have obtained under normal market conditions. ${ }^{62}$ The Court held that there is no such 'advantage' where a state financial measure must be regarded as compensation for the services provided by the recipient undertakings in order to discharge public service obligations. However, the Court identified four conditions that must be satisfied for such compensation to not be regarded as state aid in any particular case:

\footnotetext{
${ }^{61}$ European Commission (2005b).

${ }^{62}$ European Court of Justice (2003).
} 
1) The recipient must actually have public service obligations to discharge and those obligations must be clearly defined;

2) The parameters on the basis of which the compensation is calculated must be established in advance in an objective and transparent manner;

3) The compensation cannot exceed what is necessary to cover all or part of the costs incurred in the discharge of the public service obligations, taking into account the relevant receipts and a reasonable profit; and

4) Where the undertaking is not chosen in a public procurement procedure, the level of compensation must be determined by a comparison with an analysis of the costs which a typical [transport] undertaking would incur (taking into account the receipts and a reasonable profit from discharging the obligations).

Where these conditions cannot be satisfied, public service compensation will thus constitute state aid. However, the Community framework paper states that "The Commission considers that such state aid may be declared compatible with the Treaty under Article 86(2) if it is necessary to the operation of the services of general economic interest (SGEIs) and does not affect the development of trade to such an extent as would be contrary to the interests of the Community." Article 86(2) of the EC Treaty provides that services of general interest are subject "to the rules on competition, in so far as the application of such rules does not obstruct the performance, in law or in fact, of the particular tasks assigned to them”. In order for SGEIs to be compatible with the EC Treaty under Article 86(2), the following additional conditions should be met:

5) The service should be a genuine service of general economic interest within the meaning of Article 86 of the EC Treaty; and

6) there must be an instrument specifying the public service obligations and the methods of calculating compensation.

In addition, the Community framework paper states that Member States must check regularly on the absence of over-compensation - since over-compensation is not necessary for the operation of the SGEI, it constitutes incompatible state aid. 


\subsubsection{Implications for public service compensation in New Zealand}

As no state aid control regulation exists in New Zealand, no case of public service compensation has ever been tested on the possible presence of state aid. Testing public service provision in New Zealand against the European benchmark criteria as set out in the previous section would of course give some indication of the extent of potentially competition-distorting state aid provided in public sectors. It should be noted, however, that, although the European criteria are fairly generic, hypothetical New Zealand rules may need to be adapted to country-specific situations or procedures. Until such rules exist, however, the European benchmark regulation is the best (the only) alternative we can use for evaluating public service compensation in New Zealand.

It would go beyond the scope of this paper to examine all New Zealand public service areas in detail on the potential for state aid. Instead, we touch upon three typical services of general interest and identify possible compensation areas that could entail competition-distorting state aid and might need further analysis.

\section{Health}

In New Zealand, the health system is largely publicly funded. The main providers of health care services are the so-called District Health Boards (DHBs) and independent providers such as general practitioners. Total DHB funding by the government (mainly the Ministry of Health) amounted to approximately NZ\$7 billion in $2004 .^{63}$ The largest part of public funding for health services is the government's direct funding through the Vote Health programme. The other significant public sector funding source is the Accident Compensation Corporation (ACC), which pays for health care services as a result of an accident. ${ }^{64}$ This no-fault accident compensation scheme explicitly prohibits other top up supplies of insurance be provided by the private sector since $1999 .^{65}$

There is a certain degree of competition among private health care providers, but competition between public and private health care providers is still very limited. Because of this, it is difficult to identify areas of competition-distorting state aid.

\footnotetext{
${ }^{63}$ See Statistics New Zealand (2005).

${ }^{64}$ ACC payments account for approximately $7 \%$ of total health expenditure. See New Zealand Ministry of Health (2003).

${ }^{65}$ See the Victoria University Law Review (2004). Multinational accident insurance companies left the New Zealand market as a result of the accompanying legislative changes.
} 
Should more competition be introduced in the New Zealand health sector, specifically between public and private providers, risks for the provision of competition-distorting state aid may be found in the compensation the Ministry of Health pays the District Health Boards, the ACC, and other Crown entities, to the extent that it would result in an advantage vis-à-vis other providers.

\section{Education}

Public funding of education services has briefly been discussed in section 4.2.2. It is clear that education services constitute a service of general interest, which explains the state intervention in private provision of education in New Zealand. Potentially, competition-distorting state aid could be included in the financial compensation of service providers if, for example, overcompensation were to take place, or if the services to be provided or the parameters that the compensation is based on are not clearly defined in advance, as this could create an unfair advantage for certain service providers and thereby distort competition. However, as both public and private providers receive various forms of funding from the New Zealand government, it would appear that the potential for state aid in the compensation of education services within New Zealand is limited. ${ }^{66}$ However, as indicated in section 4.1.3, education is one of New Zealand's largest export services. When considering international competition between education providers in the Asia-Pacific region, the state aid discussion should be taken to a different level - whichever government (New Zealand or otherwise) creates an advantage for the service providers in that country vis-à-vis their foreign counterparts by financial (over) compensation, is providing competitiondistorting state aid that should be closely monitored, if not regulated.

\section{Energy}

Despite ongoing (but recently controlled) liberalisation in the New Zealand electricity market, the State still owns the transmission company (Transpower New Zealand Limited), and generator/retailers Mighty River Power Limited, Genesis Power Limited and Meridian Energy Limited. It seems that Article 7 of the New Zealand State-Owned Enterprises Act 1986 aims to ensure that state-owned firms do not

\footnotetext{
${ }^{66}$ Of course one can disagree with the choice of parameters or the amount of state intervention. However, as long as no advantage is created for one service provider over another (i.e. when public providers are benefited compared to private providers), this does not reflect competition-distorting state aid, but at most a case of poor political judgment.
} 
benefit from competition-distorting subsidies, as it requires that any non-commercial objectives on state-owned enterprises must be addressed through an arms-length contract. ${ }^{67}$ However, the danger of state aid provision is of course present in any stateowned company that is in direct competition with private companies. For the government not to engage in competition-distorting state aid provision, conditions 2 to 4 and 6 of the European criteria listed in the previous section are especially important. In other words, the government should make sure not to over-compensate the company, based on correct definitions, parameters, and systematic evaluation of the purposes and amount of compensation provided. As is indicated in section 2.1.2, (further) liberalisation of markets that are characterised by state-ownership should be undertaken with caution, to prevent artificial advantages for (former) state-owned firms that distort competition.

\section{Conclusion}

State aid can provide a positive contribution to the economic, and social goals that governments may have. It helps to supply those goods and services that are necessary for various economic and/or social reasons, but that are undersupplied in the market due to some form of market failure. It can also assist a country's infrastructure (broadly defined), and thereby contribute to the improvement of that country's international competitive position in trading with other countries.

Despite these reasons for the provision of state aid, there are potential inefficiencies and competition distortions that may result from it. To the extent that state aid provision creates, or has the potential to create, such inefficiencies, it should be further examined and possibly (self-)regulated. The issue is particularly important for services as these are a growing share of economic activity and trade. They are also difficult to control state aid in because the state involvement in them may be nontransparent and in some cases reflect deep political ideology.

These concerns have led to growing external monitoring and disciplines that the countries within the European Union are agreeing to have imposed on themselves. The resultant directives led to a decrease in state aid levels. They are in line with the

\footnotetext{
${ }^{67}$ Similarly, in Australia, the Hilmer report (1993) recommends that competitive neutrality between government-owned and private businesses form part of Australia’s competition policy.
} 
commitments undertaken at various European Councils, and include continued redirecting of aid towards horizontal objectives such as R\&D, small and mediumsized enterprises, environment, employment and training and regional economic development. $^{68}$ New Zealand has no such external disciplines, and yet they are important for the welfare flowing from a better balance of state aid as these external disciplines act as political checks on internal excesses.

For these external disciplines to have the mentioned balancing and welfare enhancing effects, they are best organised in an international setting in which several countries commit to the state aid rules in place (as is the case in the European Union). For New Zealand and other countries in the Asia-Pacific Region, the Asian-Pacific Economic Cooperation (APEC) forum appears to be the most likely candidate that can create and maintain a system of state aid control. If this becomes a reality, the European system of state aid rules can and should function as a benchmark to use the European experience to the advantage of the Asia-Pacific countries and ensure an efficient design, commitment and enforcement process.

\footnotetext{
${ }^{68}$ Over the period 1999-2001 to 2001-2003, the share of total aid for horizontal objectives increased by 5 percentage points. By 2003, the share of horizontal aid had risen to $79 \%$ of total aid (excluding agriculture, fisheries and transport). The remaining $21 \%$ was aid directed at specific sectors (mainly coal) including aid to rescue and restructure failing firms. See European Union (2005c).
} 


\section{REFERENCES}

Baldwin, R. E., Political economy of U.S. import policy. MIT Press, 1985

Brander, J. and B. Spencer, "Export Subsidies and International Market Share

Rivalry", Journal of International Economics, Vol. 18, February 1985, pp. 83-100

CIA, The World Factbook, 2005, www.cia.gov (viewed 5 September 2005)

Euractiv, "State aid in the new member states", 14 June 2005, www.euractiv.com (viewed 10 September 2005)

European Commission (1997a), Competition Law in the European Communities Volume IIB Explanation of the rules applicable to State aid, 1997

European Commission (1997b), Communication of the Commission to the Member States pursuant to Article 93(1) of the EC Treaty applying Articles 92 and 93 of the Treaty to short-term export-credit insurance, Official Journal of the European Communities C281, 17 September 1997

European Commission (2001), Communication of the Commission to Member States amending the communication pursuant to Article 93(1) of the EC Treaty applying Articles 92 and 93 of the Treaty to short-term export-credit insurance, Official Journal C217, 2 August 2001

European Commission (2002), European Competitiveness Report 2002

European Commission (2003a), "EU Scoreboard on State aid - twelve out of fifteen Member States fulfil Stockholm pledge to reduce aid”, Press release IP/03/595, 30 April 2003

European Commission (2003b), Green Paper on Services of General Interest, 21 May 2003

European Commission (2005a), State Aid action plan: Less and better targeted state aid: a roadmap for state aid reform 2005 - 2009, Consultation document, June 2005

European Commission (2005b), Community Framework for State Aid in the Form of Public Service Compensation, Framework paper, June 2005

European Court of Justice, Case C-63/89 Les Assurances du Crédit SA and Compagnie Belge d'Assurance Crédit SA v Council of the European Communities and Commission of the European Communities, 18 April 1999

European Court of Justice (2003), Case C-280/00 Altmark Trans GmbH and Regierungspräsidium Magdeburg v Nahverkehrsgesellschaft Altmark GmbH, 24 July 2003 
European Union (1999), Council Regulation (EC) No 659/1999 of 22 March 1999 laying down detailed rules for the application of Article 93 of the EC Treaty, Official Journal of the European Communities L83, 27 March 1999

European Union (2004a), Trade Issues, “Trade Facilitation”, http://europa.eu.int (viewed 11 September 2005, last updated September 2004)

European Union (2004b), Trade Issues, “Trade in Services”, http://europa.eu.int (viewed 22 September 2005, last updated April 2004)

European Union (2005a), "European competition policy: a brief overview - State aid control”, http://europa.eu.int (viewed 6 September 2005)

European Union (2005b), Trade Issues, “Export Credits”, http://europa.eu.int (viewed 6 September 2005)

European Union (2005c), State Aid Key Indicators, Scoreboard Spring 2005

Evans, L. and N. Quigley, “Accident Compensation: The Role of Incentives, Consumer Choice and Competition”, Victoria University Law Review, Vol. 34, No. 2, May 2004

Evans, L. and M. Richardson, “Trade reforms in New Zealand: unilateralism at work”. In Bhagwati, J.N. (ed.), Relaxed Reciprocity: Historical and Modern Experience with Unilateral Trade Liberalization, MIT Press, 2002

Evans, P. C., and K. A. Oye, "International competition: Conflict and cooperation in government export financing". In G. C. Hufbauer and R. M. Rodriguez (ed.), The ExIm bank in the 21st century: A new approach? Institute for International Economics, 2001

Financial Times, “Combative Kroes declares war on 'fat ducks’”, 26 January 2005

Findlay, R. and S. Wellisz, "Endogenous Tariffs, the Political Economy of Trade Restrictions, and Welfare”. In Bhagwati, J.N. (ed.), Import Competition and Response, University of Chicago Press, 1982

Grossman, G.M. and E. Helpman "Trade Wars and Trade Talks” Journal of Political Economy, Vol. 103, No. 4, 1995, pp. 675-708

Grossman, G.M. and E. Helpman, "Protection for Sale.” American Economic Review, Vol. 84, No. 4, 1994, pp. 833-850

Helpman, E., Politics and Trade Policy, NBER Working Paper Series, working paper 5309, Cambridge USA, October 1995

Hillman, A.L., "Declining industries and political-support protectionist motives”, American Economic Review, Vol. 72, December 1982, pp. 1180-1187 
Hilmer Committee, National Competition Policy, report for the Council of Australian Governments, Australia, August 1993

Karel, A.A.M., The Nature of Services and the Implications for Competition Policy, working paper, New Zealand Institute for the Study of Competition and Regulation, Victoria University Wellington, New Zealand, 17 May 2004

Krugman, P., Geography and Trade, MIT Press, 1991

Magee, S.P., Brock, W.A. and L. Young, Black Hole Tariffs and Endogenous Policy Formation, MIT Press, 1989

Martin S., Valbonesi, “State aid in context”. In Galli, G. and J. Pelkmans, Regulatory Reform and Competitiveness in Europe 2, Edward Elgar, 2000

Mayer, W., “Endogenous Tariff Formation”, American Economic Review, Vol. 74, No. 5, 1984, pp. 970-985

New Zealand Ministry of Education, Vote Education Budget 2002

New Zealand Ministry of Health, New Zealand Health and Disability Sector Overview, July 2003

NZ On Air, www.nzonair.govt.nz, “Organisation” (viewed 26 September 2005)

New Zealand Tertiary Education Commission, Annual Report for the 12 months ending 30 July 2004

New Zealand Trade and Enterprise, Statement of Intent 2004/5 - 2006/7, 30

September 2004

New Zealand Export Credit Office, www.nz-exportcreditoffice-agent.dk (viewed 10 September 2005)

New Zealand Ministry for the Environment, Negotiated Greenhouse Gas Agreements Guidelines, June 2005.

New Zealand Ministry of Education, Annual Report 2003/2004

Niskanen, W.A., “Should Ex-Im Bank Be Retired?”. In Hufbauer, G.C. and R.M. Rodriguez (ed.), The Ex-Im Bank in the 21st Century: A New Approach?, Special Report 14, Institute for International Economics, 2001

OECD, Arrangement on Officially Supported Export Credits, Paris, last amended 5 July 2005

Pugel, T.A. and P.H. Lindert, International Economics, $11^{\text {th }}$ edition, McGraw-Hill, USA, 2000 
Putnam, R., "Diplomacy and domestic politics: the logic of two-level games”, International Organization, Vol. 42, No. 3, 1988, pp. 427-460

Rosen, H.S., Public Finance, $4^{\text {th }}$ edition, Irwin, 1995

Statistics New Zealand, "National Accounts (Revised): Year ended March 2004”, www.stats.govt.nz (viewed 5 September 2005, last updated 13 May 2004)

Statistics New Zealand, “District Health Board Financial Statistics June 2005 quarter”, www.stats.govt.nz (viewed 22 September 2005)

Stiglitz, J., Economics of the Public Sector, $3^{\text {rd }}$ edition, W.W. Norton \& Company, 2000.

Tosini, S.C. and E. Tower, "The textile bill of 1985: The determinants of congressional voting patterns” Public Choice, Vol. 54, May 1987, pp. 19-25

Tourism New Zealand, Annual Report 2004/2005, 2005

United Kingdom Export Credits Guarantee Department, Mission Statement, www.ecgd.gov.uk (viewed 6 September 2005)

World Trade Organization (1999), An Introduction to the GATS, WTO Secretariat, October 1999

World Trade Organization (2001), Market Access: Unfinished Business, WTO Secretariat, 27 April 2001

World Trade Organization (2003), New Zealand Trade Policy Review, 14 March 2003

World Trade Organization (2004a), WTO Agriculture Negotiations - The issues, and where we are now, 1 December 2004

World Trade Organization (2004b), European Communities Trade Policy Review, 23 June 2004

World Trade Organization, General Agreement on Trade in Services, January 1995

World Trade Organization, Agreement on Subsidies and Countervailing Measures, January 1995 